\title{
Domestic Wastewater Disinfection Using Solar Radiation for Agricultural Reuse
}

\author{
R. M. Sánchez-Román，A. A. Soares，A. T. de Matos，G. C. Sediyama，O. DeSouza，A. H. Mounteer
}

\begin{abstract}
A study was performed in Viçosa, Minas Gerais, Brazil, to determine the feasibility of using solar radiation to disinfect treated domestic wastewater $(T D W W)$. The effluent from a residential development, after passing through a pre-treatment unit (bar screen and grit channel) and a septic tank, was used as supply. After the septic tank, the TDWW had mean values of $286 \mathrm{mg} \mathrm{L}^{-1} \mathrm{COD}, 54 \mathrm{mg} \mathrm{L}^{-1} \mathrm{TSS}$, and $65 \mathrm{NTU}$ turbidity. A square cement block reactor was constructed (located at $\left.20^{\circ} 45^{\prime} 14^{\prime \prime} \mathrm{S}, 42^{\circ} 52^{\prime} 53^{\prime \prime} \mathrm{W}\right)$ and used to disinfect the reclaimed TDWW. Fixed depths of water $(0.05,0.10$, 0.15 , and $0.20 \mathrm{~m}$ ) were tested at different exposure times from November 2004 to May 2005. Solar UV disinfection (SODIS) was effective in reducing mean concentration of indicator microorganisms, i.e., total coliform (TC) and Escherichia coli (E. coli), after $8 \mathrm{~h}$ of exposure to direct sunlight. Statistical analysis showed that the inactivation rates of E. coli did not significantly vary due to turbidity or dissolved oxygen. A model was developed to estimate the surviving E. coli population after SODIS from its initial population, depth of water treated, and solar energy received. The model indicated that, for a fluence accumulated of $32.91 \mathrm{MJ} \mathrm{m}^{-2}$, a 4 log reduction of $\mathrm{E}$. coli population was achieved with a wastewater depth of $0.05 \mathrm{~m}$ in the SODIS reactor.
\end{abstract}

Keywords. Domestic wastewater disinfection, E. coli, SODIS, Water reuse.

L ack of water, water sanitation, and healthcare, as well as hunger and poverty, affects billions of human beings. These problems will become worse in the coming decades (Postel, 2000; Rosegrant et al., 2002). A large portion of the daily human water requirement for survival is returned to the environment in the form of domestic wastewater (DWW). The use of DWW in agriculture involves important social and environmental aspects, such as water demand and supply to agriculture, increasing fertilizer prices, crop nutrient demand, environmental protection, and wastewater disposal. Perhaps even more importantly, it relates to food production and supply, especially for low-income third world households. According to Strauss (2000), about $10 \%$ of the world's sewer water is used for fertigation of agricultural crops, and this portion may be as high as $80 \%$ in developing countries (Cooper, 1991).

Human excrement is an important source of nutrients for plants. Every day, a typical person excretes around $30 \mathrm{~g}$ of carbon (90 $\mathrm{g}$ of organic matter), 10 to $12 \mathrm{~g}$ of nitrogen, $2 \mathrm{~g}$ of

Submitted for review in May 2006 as manuscript number SW 6492; approved for publication by the Soil \& Water Division of ASABE in November 2006.

The authors are Rodrigo Máximo Sánchez-Román, ASABE Member, CAPES (PEC-PG) Fellow, Departamento de Engenharia Rural, Universidade de São Paulo, Campus Luiz de Queiroz, São Paulo, Brazil; Antonio A. Soares, Professor, Antonio T. de Matos, Associate Professor, and Gilberto C. Sediyama, Professor, Departamento de Engenharia Agrícola (DEA), Universidade Federal de Viçosa (UFV), Minas Gerais, Brazil; Og DeSouza, Associate Professor, Department of Animal Biology, and Ann H. Mounteer, Associate Professor, Department of Civil Engineering, Universidade Federal de Viçosa (UFV), Minas Gerais, Brazil Corresponding author: Rodrigo M. Sánchez-Román, Universidade de São Paulo, Campus Luiz de Queiroz, Depto. de Engenharia Rural, Av. Pádua Dias 11, Agronomia, Piracicaba, SP 13418-900, Brazil; phone: (19)3447-8556; fax: (19)3435-1840; e-mail: rsanchezr@asabe.org. phosphorus, and $3 \mathrm{~g}$ of potassium. In one year, one person generates approximately $500 \mathrm{~L}$ of urine and $50 \mathrm{~L}$ of feces, equivalent to fertilizer sufficient to produce $250 \mathrm{~kg}$ of cereals (Windland et al., 1999; Drangert, 1998).

However, DWW cannot be used indiscriminately in agricultural since human feces contain microorganisms that can be potentially harmful to human health. It is possible to use DWW as a secure water source for agriculture; however, some prophylactic actions are necessary. It is important to avoid contamination created by the presence of pathogens, thus eliminating the sanitary risks presented by DWW (Drechsel et al., 2002). For use in developing countries, the pathogen elimination system should have low maintenance and operation costs, be sustainable with local resources, and use appropriate technology to guarantee system viability (Strauss, 2000).

Solar radiation is the radiant energy emitted from the sun that reaches earth's surface. The magnitude of solar radiation is the amount of radiant energy of a given wavelength interval that crosses a unit area perpendicular to its direction per unit time $\left(\mathrm{W} \mathrm{m}^{-2}\right)$, while irradiance is the radiant flux incident on a receiving surface from all directions per unit area of surface $\left(\mathrm{W} \mathrm{m}^{-2}\right)$ (Liou, 1980; Iqbal, 1983). For solar disinfection, one is concerned with the fluence, or dose, which refers to the total amount of energy applied per unit area, that is, the irradiance multiplied by the exposure time $\left(\mathrm{J} \mathrm{m}^{-2}\right)$.

Solar radiation varies in intensity and is unevenly distributed on our planet, depending on geographical location, cloudiness, time of day, and season. According to Acra et al. (1984), solar disinfection (SODIS) is a practical solution in the regions between latitudes $35^{\circ} \mathrm{N}$ and $35^{\circ} \mathrm{S}$, where the great majority of the developing countries are located. The most favorable regions for SODIS lie between latitudes $15^{\circ}$ and $35^{\circ}$ north and south; the second best region for SODIS lies between $15^{\circ} \mathrm{N}$ and $15^{\circ} \mathrm{S}$. 
Acra et al. (1984) compared the germicidal effects of different wavelengths of light on bacteria and concluded that the highest bactericidal wavelengths that reach the surface of the earth's surface are between 315 and $400 \mathrm{~nm}$. They also demonstrated that $E$. coli is the best indicator organism for measuring efficiency of solar disinfection since it is more resistant to the lethal effects of sunlight than other populations of fecal coliforms. Studies carried out by Acra et al. (1997) proved the bactericidal effect of the solar UV rays in water disinfection.

Wegelin et al. (1994), Joyce et al. (1996), Solarte et al. (1997), Saitoh and El-Ghetany (2002), and Caslake et al. (2004) evaluated the synergism between UV exposition, water temperature, and turbidity in disinfection of water for human consumption. McGuigan et al. (1998) and Oates et al. (2003) reported that it is possible to achieve $100 \%$ E. coli inactivation in less than $8 \mathrm{~h}$ of solar exposition. Kehoe et al. (2001) and Burgess et al. (2002) found that the presence of dissolved oxygen and a reflective surface improved bacterial removal efficiency, while increasing turbidity decreased bacterial inactivation rates.

Wegelin et al. (1994) verified that bacterial logarithmic inactivation curves are generally concave and present an early lag-time phase. This lag-time phase, when graphed, is a "shoulder" that corresponds to the delay before which UV produces a lethal effect in bacteria due to bacterial DNA repair mechanisms. After this period has elapsed, the curve drops off rapidly.

Salih (2003) developed a mathematical model to predict the efficiency of SODIS that considered solar UV exposure and the initial contamination load as independent variables. Using $6 \times 9 \mathrm{~mm}$ wells, $3.54 \mathrm{~mm}$ water depth, and samples prepared with sterilized raw stream water and a wild type of E. coli, the author found that around $8.88 \times 10^{3} \mathrm{~kJ} \mathrm{~m}^{-2}$ exposure was required to reduce the bacterial population by five $\log$ cycles. Yoon et al. (2004) disinfected DWW effluent from a secondary wastewater treatment plant using UV lamps and found that the use of treated DWW for agricultural purposes in Korea is an effective and viable alternative.

Limitations of the studies that have been carried out on DWW disinfection using UV radiation for application by low-income families living in developing countries include: (1) the processes required UV lamps or structures that were too complicated to be built and maintained when using sunlight as the energy source treating DWW, (2) most of the studies considered water disinfection for human consumption and not for crop production, and (3) most of the systems required power supplies, which are often unavailable in rural areas of developing countries.

This study thus sought to develop a DWW treatment technology that is simple and allows for subsequent use of DWW in agriculture. The objective was not to produce potable water but to reduce the pathogen load to levels suggested by WHO (1989) for irrigation water without restrictions $(\leq 1,000$ MPN fecal coliforms per $100 \mathrm{~mL})$, and to develop a model to simulate pathogen mortality using the solar disinfection process.

\section{Material ANd Methods \\ SOLAR DisinfECTION UNIT}

A square reactor (fig. 1), called the solar disinfection unit or SODIS unit, was constructed at the Experimental Station

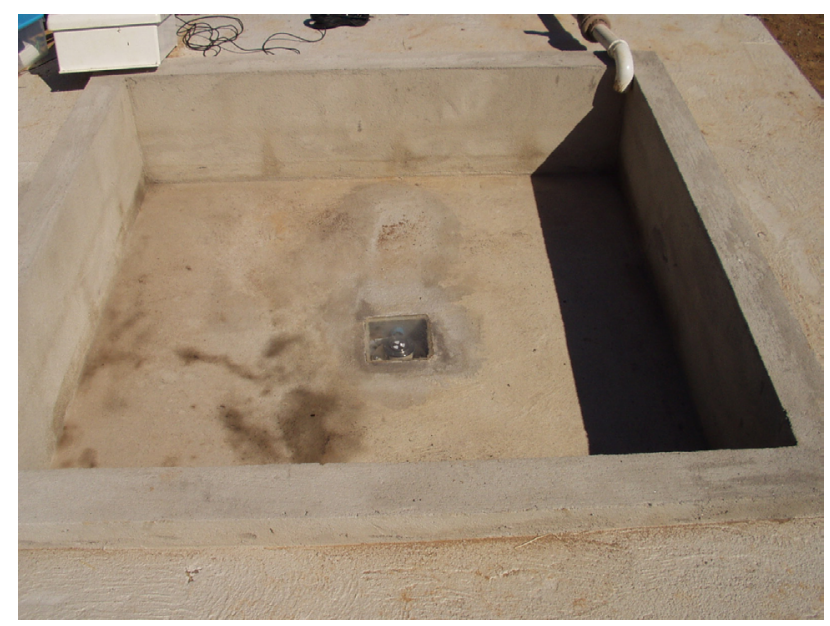

Figure 1. Solar disinfection unit.

for Reclamation of Domestic Wastewater for Agriculture Use (ESRDWW-AU) of the Department of Agricultural Engineering, Universidade Federal de Viçosa, State of Minas Gerais, Brazil. The solar disinfection unit is made of concrete blocks. Its base measures $1.5 \times 1.5 \mathrm{~m}$ with a height of $0.4 \mathrm{~m}$. It has vertical walls and a northern orientation. The walls and bottom have a raw concrete finish.

The reactor was located at $20^{\circ} 45^{\prime} 14^{\prime \prime} \mathrm{S}$ and $42^{\circ} 52^{\prime} 53^{\prime \prime}$ $\mathrm{W}$, at an altitude of $648.74 \mathrm{~m}$ above sea level. The ESRDWW-AU can handle $2 \mathrm{~L} \mathrm{~s}^{-1}$ of DWW from a nearby residential development. The DWW was pumped to a pre-treatment unit (bar screen and grit channel) and then passed through a concrete septic tank (ABNT, 1993) with a residence time of approximately $14 \mathrm{~h}$ to produce treated domestic wastewater (TDWW). The TDWW was diverted to the SODIS unit using $115.6 \mathrm{~m}$ of PVC pipe (50 mm internal diameter).

\section{Sample Treatment, Collection, and Analysis}

Trials were conducted in November 2004, March 2005, April 2005, and May 2005 under different conditions of cloud cover, for a total of 20 days. The TDWW was conveyed to the SODIS unit at $0.35 \mathrm{~m}$ above the bottom of the reactor. Before each test, the inflow and the outflow valves were opened for 15 min to purge the TSS that had deposited during the night on the bottom of the pipeline connecting the septic tank and SODIS unit. The valve at the bottom of the SODIS unit was then closed, and the required TDWW height was set for each trial. The air temperature ranged between $13.1^{\circ} \mathrm{C}$ and $30.4^{\circ} \mathrm{C}$ during the trials. Trials were performed starting at 8:00 a.m. and ran for 8 to $10 \mathrm{~h}$, guaranteeing exposure to around $90 \%$ of the sunlight availability on every trial day.

Samples were collected according to Standard Method 1060B (APHA, 1995) and preserved according to Standard Method 1060C (APHA, 1995). TDWW was sampled on the southern part of the disinfection unit. The first collection was done just after the desired water level was reached. Thereafter, samples were collected every $2 \mathrm{~h}$ up to the end of each trial. A total of 106 sets were collected.

A set of three samples were collected at each collection time: the first for microbiological analysis, the second for dissolved oxygen (DO), and the third for chemical oxygen demand (COD), total suspended solids (TSS), and turbidity. All analyses were performed according to Standard Methods (APHA, 1995): 
Table 1. Variables and interactions between variables that were evaluated in developing a model for solar disinfection of treated domestic wastewater.

\begin{tabular}{lcc}
\hline Variable & Variable & Units \\
\hline Fluence & $x_{1}$ & $\mathrm{MJ} \mathrm{m}^{-2}$ \\
Depth & $x_{2}$ & $\mathrm{~m}$ \\
Temperature & $x_{3}$ & ${ }^{\circ} \mathrm{C}$ \\
Turbidity & $x_{4}$ & $\mathrm{NTU}$ \\
Dissolved oxygen & $x_{5}$ & $\mathrm{mg} \mathrm{L}^{-1}$ \\
Total suspended solid & $x_{6}$ & $\mathrm{mg} \mathrm{L}^{-1}$ \\
Chemical oxygen demand & $x_{7}$ & $\mathrm{mg} \mathrm{L}^{-1}$ \\
\hline Interaction of variables: & & \\
\multicolumn{1}{c}{ Fluence : Temperature } & $x_{1: 3}$ & $\mathrm{MJ} \mathrm{m}^{-2}{ }^{\circ} \mathrm{C}$ \\
\multicolumn{1}{c}{ Fluence : Depth } & $x_{1: 2}$ & $\mathrm{MJ} \mathrm{m}^{-2} \mathrm{~m}$ \\
Fluence : Turbidity & $x_{1: 4}$ & $\mathrm{MJ} \mathrm{m}^{-2} \mathrm{NTU}$ \\
Depth : Temperature & $x_{2: 3}$ & $\mathrm{~m}^{\circ} \mathrm{C}$ \\
Depth : Turbidity & $x_{2: 4}$ & $\mathrm{~m} \mathrm{NTU}^{\circ}$ \\
Fluence : Depth : Temperature & $x_{1: 2: 3}$ & $\mathrm{MJ} \mathrm{m}^{-2} \mathrm{~m}{ }^{\circ} \mathrm{C}$ \\
Fluence : Depth : Turbidity & $x_{1: 2: 4}$ & $\mathrm{MJ} \mathrm{m}^{-2} \mathrm{~m} \mathrm{NTU}^{\circ}$
\end{tabular}

- DO: Standard Method 4500-OC.

- Turbidity: Standard Method 2130B (turbidimeter: TB1000, Companhia da Água, Brazil).

- COD: Standard Method 5220B.

- TSS: Standard Method 2540D (filter paper: MN 85/70 BF Ø47 mm, $0.6 \mu \mathrm{m}$, Machenery-Nagel, Germany).

- Water temperature: Standard Method 2550 (mercury thermometer: $-30^{\circ} \mathrm{C}$ to $250^{\circ} \mathrm{C}$ range, Revitec, Brazil).

Wastewater samples from the solar disinfection unit were tested for total coliforms and $E$. coli using the chromogenic substrate test: Standard Method 9223B (Quanti-Tray/2000, IDEXX Laboratories, Inc., Westbrook, Maine). The limit of detection is $<1$ coliform per $100 \mathrm{~mL}$ of water.

\section{Solar Radiation Measurement}

An automatic weather station with a pyranometer sensor (model LI-200SZ, Li-Cor, Lincoln, Neb.), with sensitivity of $80 \mu \mathrm{A}$ per $1,000 \mathrm{~W} \mathrm{~m}^{-2}$ and spectral response curve between 395 and $1105 \mathrm{~nm}$, was installed near the experiment. Data were stored at half-hour intervals. The pyranometer was calibrated using a black and white pyranometer (model 8-48, The Eppley Laboratory, Inc., Newport, R.I.).

\section{Data Analysis}

Water analysis results were expressed according to Standard Method 1050. The bacterial population reduction in the exposed TDWW was analyzed using the Statistical Package R (version 2.1.0, The R Foundation for Statistical Computing).

Considering the binary nature of the response variable indicating the surviving microorganisms as a proportion of their initial population after exposition to SODIS, the logit regression model was applied during modeling to fit the data. Thus, the predicted values for the dependent variable will never be less than or equal to zero, nor greater than or equal to one, regardless of the value of the independent variables. The S-shaped two-parameter logistic function (Ratkowsky, 1989; Crawley, 2002) was used to adjust the data. The logistic function is used in analysis of survival, dose-response studies of microorganisms exposed to ultraviolet radiation or any other biocidal (Kowalski et al., 2000). The form of this function for water disinfection can be written as:
Table 2. Mean, maximum, minimum, and standard deviation values for the collected data.

\begin{tabular}{|c|c|c|c|c|c|}
\hline Parameter[a] & Units & Mean & Max. & Min. & SD \\
\hline \multicolumn{6}{|l|}{ Depth $=0.05 \mathrm{~m}$} \\
\hline Dose & $\mathrm{MJ} \mathrm{m}^{-2}$ & 8.12 & 20.90 & 0.00 & 6.25 \\
\hline TSS & $\mathrm{mg} \mathrm{L}^{-1}$ & 40.87 & 116 & 2 & 26.06 \\
\hline Turbidity & NTU & 67.97 & 140 & 26 & 28.88 \\
\hline TDWW temp. & ${ }^{\circ} \mathrm{C}$ & 29.5 & 36.0 & 23.5 & 4.1 \\
\hline DO & $\mathrm{mg} \mathrm{L}^{-1}$ & 1.78 & 6.13 & 0.00 & 2.28 \\
\hline COD & $\mathrm{mg} \mathrm{L}^{-1}$ & 306.69 & 529 & 120 & 130.99 \\
\hline \multicolumn{6}{|l|}{ Depth $=0.10 \mathrm{~m}$} \\
\hline Dose & $\mathrm{MJ} \mathrm{m}^{-2}$ & 7.77 & 17.91 & 0.00 & 5.58 \\
\hline TSS & $\mathrm{mg} \mathrm{L}^{-1}$ & 30.16 & 79 & 6 & 14.16 \\
\hline Turbidity & NTU & 51.04 & 100 & 9 & 32.99 \\
\hline TDWW temp. & ${ }^{\circ} \mathrm{C}$ & 28.5 & 33.0 & 22.0 & 2.9 \\
\hline DO & $\mathrm{mg} \mathrm{L}^{-1}$ & 1.68 & 6.58 & 0.00 & 2.37 \\
\hline COD & $\mathrm{mg} \mathrm{L}^{-1}$ & 177.35 & 340 & 59 & 55.63 \\
\hline \multicolumn{6}{|l|}{ Depth $=0.15 \mathrm{~m}$} \\
\hline Dose & $\mathrm{MJ} \mathrm{m}^{-2}$ & 6.10 & 14.72 & 0.00 & 4.55 \\
\hline TSS & $\mathrm{mg} \mathrm{L}^{-1}$ & 22.86 & 44 & 8 & 9.97 \\
\hline Turbidity & NTU & 23.57 & 50 & 11 & 12.40 \\
\hline TDWW temp. & ${ }^{\circ} \mathrm{C}$ & 24.3 & 27.5 & 19.0 & 2.6 \\
\hline DO & $\mathrm{mg} \mathrm{L}^{-1}$ & 1.37 & 6.48 & 0.00 & 1.96 \\
\hline COD & $\mathrm{mg} \mathrm{L}^{-1}$ & 157.05 & 238 & 80 & 51.92 \\
\hline \multicolumn{6}{|l|}{ Depth $=0.20 \mathrm{~m}$} \\
\hline Dose & $\mathrm{MJ} \mathrm{m}^{-2}$ & 8.27 & 14.57 & 0.00 & 5.03 \\
\hline TSS & $\mathrm{mg} \mathrm{L}^{-1}$ & 54.78 & 261 & 17 & 49.25 \\
\hline Turbidity & NTU & 49.35 & 80 & 30 & 16.88 \\
\hline TDWW temp. & ${ }^{\circ} \mathrm{C}$ & 22.9 & 26.5 & 18.0 & 2.5 \\
\hline DO & $\mathrm{mg} \mathrm{L}^{-1}$ & 0.03 & 0.63 & 0.00 & 0.13 \\
\hline COD & $\mathrm{mg} \mathrm{L}^{-1}$ & 275.21 & 880 & 160 & 146.96 \\
\hline
\end{tabular}

a] TSS = total suspended solids, TDWW = treated domestic wastewater, $\mathrm{DO}=$ dissolved oxygen, and $\mathrm{COD}=$ chemical oxygen demand .

$$
N / N_{0}=\frac{e^{\left(a_{0}+b_{1} x_{1}+b_{2} x_{2}+\ldots+b_{14} x_{1: 2: 4}\right)}}{1+e^{\left(a_{0}+b_{1} x_{1}+b_{2} x_{2}+\ldots+b_{14} x_{1: 2: 4}\right)}}
$$

where $N$ is the $E$. coli population present in the TDWW after exposure to solar radiation (MPN/100 mL), $N_{0}$ is the initial E. coli population present in the TDWW before exposure to solar radiation (MPN/100 mL), and $x_{[1 \ldots 4]}$ are independent variables with their respective coefficients $\left.b_{[1} \ldots 14\right]$. These independent variables and the interactions between variables were evaluated in this study, as listed in table 1.

Data were analyzed using a linear mixed-effects model, fit by maximum likelihood, with energy as fixed effect and each trial as random effects. The hypothetical probability that an event that has already occurred will yield a specific outcome, referring to past events with known outcomes, is called likelihood, and the maximum likelihood method finds the values of the parameters of a set of statistical data that maximize the likelihood distribution. Ten different statistical models were built by combining the independent variables listed in table 1 in several ways. The best fit model is that which presents the lowest Akaike information criterion (AIC $=-2 \log$ Likelihood $+2[$ number of parameters in the model +1$])$ and the lowest Bayesian information criterion $(\mathrm{BIC}=-2 \log$ Likelihood $+[$ number of parameters in the model $\times \log$ sample size $]$ ).

The Akaike information criterion (AIC), also called penalized log likelihood, is useful when comparing models because it explicitly penalizes any superfluous parameters in 

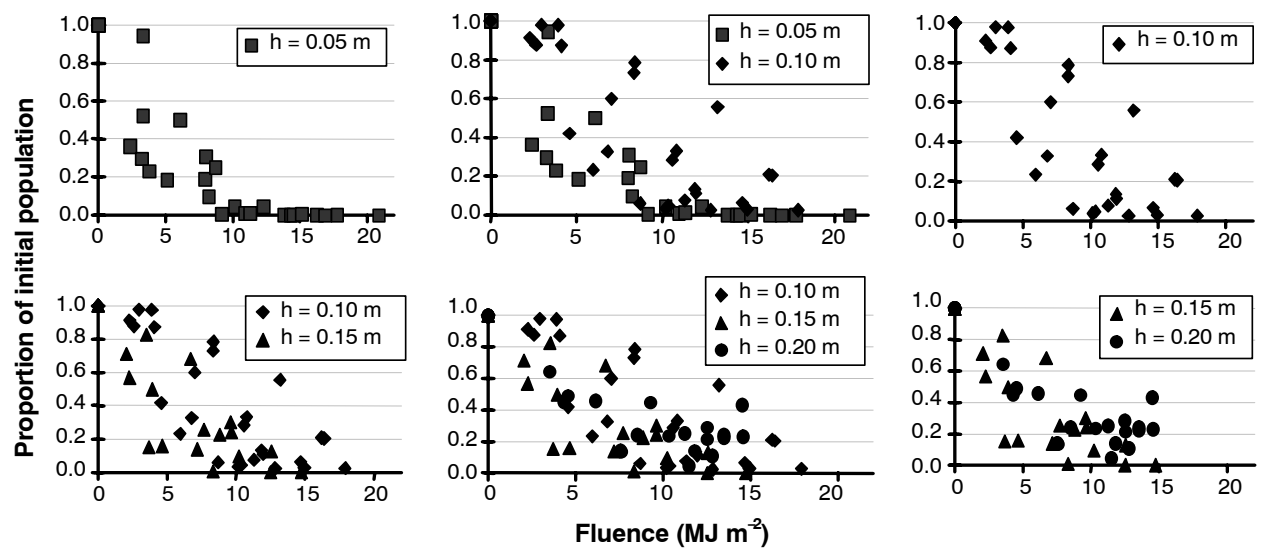

Figure 2. Proportion of initial population of $E$. coli as a function of fluence and treated domestic wastewater depth when solar disinfection (SODIS) was used.

the model. It is especially useful when non-linear mixed-effects models are being compared. AIC can be used to compare two models in the same way that the analysis of variance does. The data collected, i.e., survival of $E$. coli after exposure to solar radiation, is the result of UV radiation energy absorbed (dose) by the $E$. coli's DNA, which directly affects the viability of these microorganisms. Therefore, the interest in model fitting using mixed effects is the variance explained by random effects, not the effect sizes (Crawley, 2002).

\section{Results AND Discussion}

The TDWW entering the solar reactor contained up to $96 \times 10^{6} \mathrm{MPN} / 100 \mathrm{~mL}$ total coliforms and $15.65 \times 10^{6}$ MPN/ $100 \mathrm{~mL}$ E. coli. The mean TDWW values entering the SODIS unit were $13.6 \times 10^{6} \mathrm{MPN} / 100 \mathrm{~mL}$ total coliforms and $3 \times 10^{6} \mathrm{MPN} / 100 \mathrm{~mL}$ E. coli, and the values in the effluent after SODIS treatment were as low as $1460 \mathrm{MPN} /$ $100 \mathrm{~mL}$ total coliforms and $100 \mathrm{MPN} / 100 \mathrm{~mL}$ E. coli. Water quality parameters such as COD and DO varied over the course of the trials (table 2); however, no significant differences were found.

The energy required to reach low levels of $N / N_{0}$ decreased as water depth decreased (fig. 2). The E. coli inactivation curve showed a typical S-shaped behavior, as in analysis of survival data, with an initial exponential decay response delayed briefly (lag-time phase) and two stage of inactivation, which is in agreement with results presented by Severin et al. (1983), Wegelin et al. (1994), Kehoe et al. (2001), Kowalski (2001), and Salih (2003).

Chick's law (Metcalf and Eddy, 1979), which is the simplest form of describing microbial inactivation, does not describe the observed trends in the data collected in this study. The multi-target survival model used by Salih (2003), which takes into consideration the presence of a lag-time phase and two stages of inactivation, is more suited to the results obtained in this study. According to Wegelin et al. (1994), the multi-target survival model is applicable to pure bacterial strains under laboratory and sunlight irradiation, while the two-stage survival model is suited for use in modeling two separate populations of microorganisms that have different decay rates (Kowalski, 2001). However, for the present study, the multi-target survival model is also of limited use, since it does not consider the water depth and given that the population decay rates for individual populations are not known, nor are they readily determined. This underscores the need for development of a more easily applied disinfection model for use in design and operation of solar reactors.

There was no great difference in fit between model I, which included dose (fluence) and depth as independent variables, and model II, which used dose and temperature (table 3). According to the principle of parsimony (Ockham's razor), model I is recommended for use since it presented the lowest values for AIC (504.71) and BIC (523.35), and it included only the readily measurable variables (dose and wastewater depth) and not terms for interactions between variables. Furthermore, statistical analysis of the data obtained indicated that three parameters are important in SODIS of TDWW: initial E. coli population, depth of wastewater, and fluence. Turbidity, DO, TSS, and COD were not statistically significant when $E$. coli survival was modeled (data not shown).

The S-shaped logistic function (eq. 2) based on model I is therefore:

$$
\frac{N}{N_{0}}=\frac{\exp (1.047-0.321 F+6.304 d)}{[1+\exp (1.047-0.321 F+6.304 d)]}
$$

where $N$ is the $E$. coli population present in the TDWW after exposure to solar radiation (MPN/100 mL), $N_{0}$ is the initial E. coli population present in the TDWW before exposure to solar radiation (MPN/100 mL), $F$ is the fluence received by the TDWW (MJ m$\left.{ }^{-2}\right)$, and $d$ is the TDWW depth in the solar reactor $(\mathrm{m})$. The maximum depth tested was $0.20 \mathrm{~m}$. The coefficients in model I (eq. 2) were all highly significant ( $\mathrm{p}=$ 0.0007 for intercept, $p<0.0001$ for fluence, and $p=0.006$ for depth). The standard deviations for random effects were $3.6 \times 10^{-7}$ for intercept and $2.1 \times 10^{-7}$ for fluence.

Figure 3 illustrates the model proposed in this article (eq. 2), the survival ratio of $E$. coli over the range of depths studied, and fluence values measured during the experimental trials. It is clear that photons of light are absorbed or scattered when they reach water (Kirk, 1994) and that shallower TDWW depths required less energy than deeper depths. This is not only because of the attenuation of light through the wastewater, but also because of the expected proportional increase in the absolute number of microorganisms that have to be hit by the same amount of photons of light to be inactivated throughout a deeper water column. 
Table 3. Models generated to describe solar radiation disinfection of treated domestic wastewater.

\begin{tabular}{|c|c|c|c|}
\hline \multicolumn{2}{|c|}{ Model Regression[a] } & \multirow{2}{*}{$\begin{array}{l}\mathrm{AIC}^{\mathrm{b}]} \\
504.71\end{array}$} & \multirow{2}{*}{$\begin{array}{c}\mathrm{BIC}^{[\mathrm{b}]} \\
523.35\end{array}$} \\
\hline I & $\begin{array}{r}N / N_{0}=\exp (1.047-0.321 F+6.304 d) / \\
{[1+\exp (1.047-0.321 F+6.304 d)]}\end{array}$ & & \\
\hline II & $\begin{array}{r}N / N_{0}=\exp (5.546-0.184 F-0.16 T p-0.003 F . T p) / \\
{[1+\exp (5.546-0.184 F-0.16 T p-0.003 F . T p)]}\end{array}$ & 507.49 & 528.79 \\
\hline III & $\begin{array}{r}N / N_{0}=\exp (7.555-2.106 F+17.27 d-0.127 T p+0.042 F . T p+2.07 F . d-1.42 \mathrm{~d} . T p+0.096 F . d . T p) / \\
{[1+\exp (7.555-2.106 F+17.27 d-0.127 T p+0.042 F . T p+2.07 F . d-1.42 \mathrm{~d} . T p+0.096 F . d . T p)]}\end{array}$ & 518.46 & 550.42 \\
\hline IV & $\begin{aligned} N / N_{0} & =\exp (-0.857-0.283 F+14.17 d+0.046 t b+0.04 F . d-0.004 F . t b-0.27 d . t b+0.028 F . d . t b) / \\
{[1} & +\exp (-0.857-0.283 F+14.17 d+0.046 t b+0.04 F . d-0.004 F . t b-0.27 d . t b+0.028 F . d . t b)]\end{aligned}$ & 518.83 & 550.79 \\
\hline $\mathrm{V}$ & $\begin{array}{r}N / N_{0}=\exp (1.383-0.517 F-4.33 d+0.015 t b+1.91 F . d-0.001 F . t b) / \\
{[1+\exp (1.383-0.517 F-4.33 d+0.015 t b+1.91 F . d-0.001 F . t b)]}\end{array}$ & 519.51 & 546.15 \\
\hline VI & $\begin{array}{r}N / N_{0}=\exp (-0.459) / \\
{[1+\exp (-0.459)]}\end{array}$ & 520.55 & 533.87 \\
\hline VII & $\begin{array}{l}N / N_{0}=\exp \left(4.7 \times 10^{15}-1.2 \times 10^{13} \mathrm{~F}-6.9 \times 10^{14} d-2 \times 10^{14} \mathrm{Tp}+5.5 \times 10^{12} t b+3.4 \times 10^{13} \mathrm{DO}+7.5 \times 10^{12} \mathrm{TSS}+6.8 \times 10^{11} \mathrm{COD}\right) / \\
\quad\left[1+\exp \left(4.7 \times 10^{15}-1.2 \times 10^{13} \mathrm{~F}-6.9 \times 10^{14} d-2 \times 10^{14} \mathrm{Tp}+5.5 \times 10^{12} t b+3.4 \times 10^{13} \mathrm{DO}+7.5 \times 10^{12} \mathrm{TSS}+6.8 \times 10^{11} \mathrm{COD}\right)\right]\end{array}$ & 7871.79 & 7903.75 \\
\hline VIII & $\begin{array}{r}N / N_{0}=\exp (7.743-0.311 T p) / \\
{[1+\exp (7.743-0.311 T p)]}\end{array}$ & 525.20 & 541.18 \\
\hline IX & $\begin{array}{r}N / N_{0}=\exp (2.903-0.667 F-7.33 d+2.272 F . d) / \\
{[1+\exp (2.903-0.667 F-7.33 d+2.272 F . d)]}\end{array}$ & 531.12 & 552.43 \\
\hline $\mathrm{X}$ & $\begin{array}{r}N / N_{0}=\exp (3.496-0.646 F-7.67 d-0.023 T p+2.19 F . d) / \\
\quad[1+\exp (3.496-0.646 F-7.67 d-0.023 T p+2.19 F . d)]\end{array}$ & 532.32 & 556.29 \\
\hline
\end{tabular}

[a] $N=$ E. coli population after certain dose has been applied (MPN $/ 100 \mathrm{~mL}), N_{0}=$ initial $E$. coli population (MPN $\left./ 100 \mathrm{~mL}\right), F=$ fluence $\left(\mathrm{MJ} \mathrm{m}^{-2}\right), d=$ water $^{-1}$ depth $(\mathrm{m}), T p=$ temperature $\left({ }^{\circ} \mathrm{C}\right), t b=$ turbidity $(\mathrm{NTU}), \mathrm{DO}=$ dissolved oxygen $\left(\mathrm{mg} \mathrm{L}^{-1}\right), \mathrm{TSS}=$ total suspended solids $\left(\mathrm{mg} \mathrm{L}^{-1}\right)$, and $\mathrm{COD}=\mathrm{chemical}$ oxygen demand $\left(\mathrm{mg} \mathrm{L}^{-1}\right)$.

[b] $\mathrm{AIC}=$ Akaike information criterion; $\mathrm{BIC}=$ Bayesian information criterion.

Sunlight has a germicidal action that has been recognized since 1877, when Downes and Blunt researched the effect of light on bacteria and other organisms. The survival ratio of bacteria killed by radiation is a function of exposure, in accordance with the Bunsen-Roscoe reciprocity law, regardless of whether the exposure is of a high intensity for a short time or a low intensity for a correspondingly longer time (Koller, 1952).

Improvements in constructive aspects of the solar reactor should be studied. The surface reflectance of the internal walls and bottom of the reactor should be improved to create an environment in which indirect radiation as well as direct

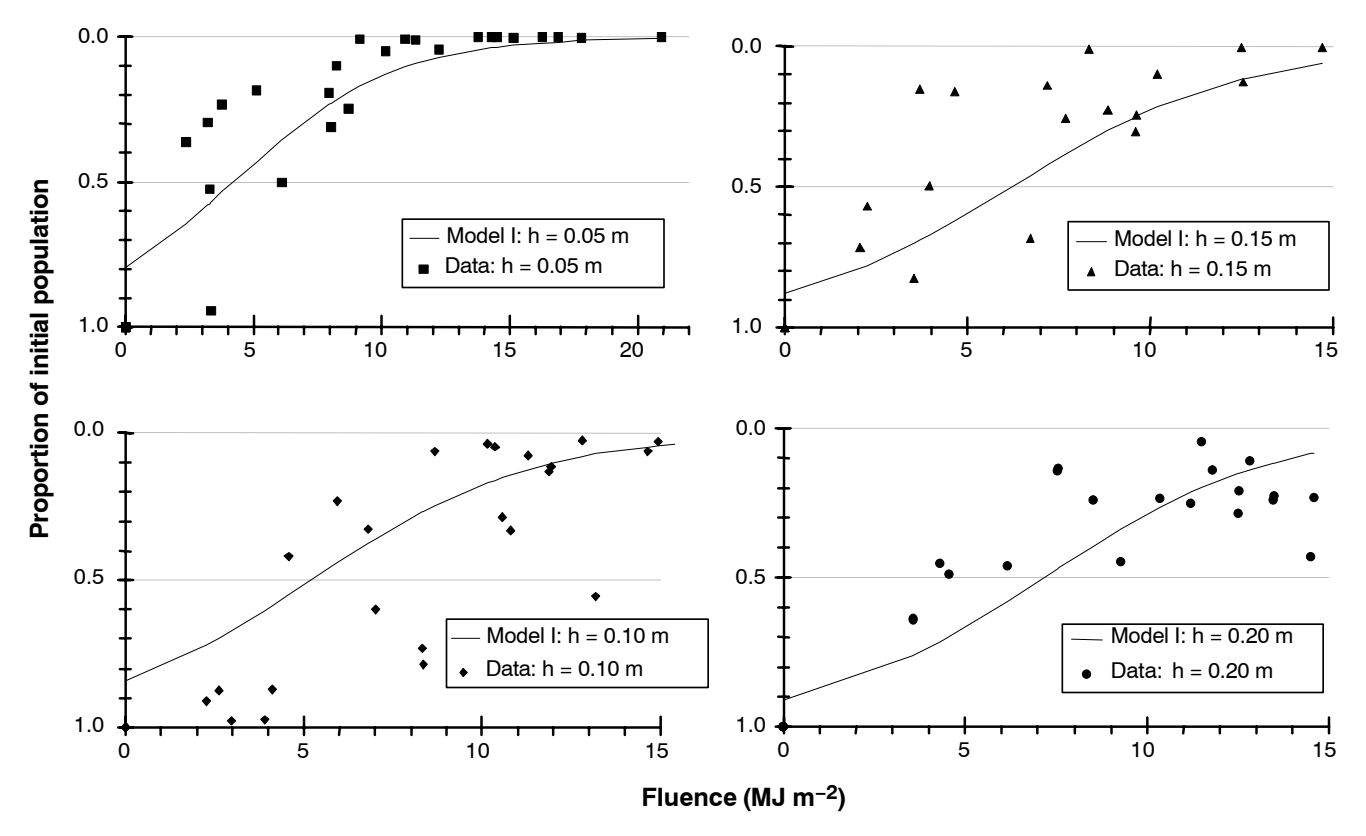

Figure 3. Treated domestic wastewater solar disinfection modeled using equation 2. radiation is used. In addition, although vertical walls are simpler to build, we recommend that the wall facing the sun be sloped at an angle equal to the latitude where the reactor is located. This would increase the incidence of radiation, since shadows created by the solar reactor's walls would be diminished.

The amount of energy necessary to disinfect TDWW, in a certain location, is not a value that can be established as hours of exposure, but rather as a dose applied (fluence accumulated), which depends mainly on the season of the year and the latitude. Therefore, no recommendation can, or should, be made in terms of exposure time. As an example,

The 3. Theated domestic wastewater solar disinfection modeled using equation 2. 
Table 4. Solar radiation (MJ m-2 $\mathrm{d}^{-1}$ ) for three locations.

\begin{tabular}{clc}
\hline $\begin{array}{c}\text { Date of } \\
\text { Analysis }\end{array}$ & Location & $\begin{array}{c}\text { Solar Radiation } \\
\left(\mathrm{MJ} \mathrm{m}^{-2} \text { day }^{-1}\right)\end{array}$ \\
\hline \multirow{3}{*}{ 15 February } & Antofagasta, Chile & 20.6 \\
& Mogadishu, Somalia & 19.1 \\
& Bombay, India & 16.0 \\
\hline \multirow{3}{*}{15 August } & Antofagasta, Chile & 15.6 \\
& Mogadishu, Somalia & 20.6 \\
& Bombay, India & 21.8 \\
\hline
\end{tabular}

considering an initial E. coli population of $3.5 \times 10^{6}$ MPN/100 mL, a domestic wastewater depth of $0.05 \mathrm{~m}$ and a desired final population of $E$. coli equal to $1,000 \mathrm{MPN} /$ $100 \mathrm{~mL}$, the total energy required will be at least $29.65 \mathrm{MJ}$ $\mathrm{m}^{-2}$. For the same conditions, if the water depth is increased to $0.20 \mathrm{~m}$, the total energy demanded will be at least $32.59 \mathrm{MJ}$ $\mathrm{m}^{-2}$. Table 4 lists the solar radiation computed for three locations around the world, Antofagasta, Chile $\left(23^{\circ} 38^{\prime} 30^{\prime \prime} \mathrm{S}\right)$, Mogadishu, Somalia $\left(1^{\circ} 48^{\prime} 2^{\prime \prime} \mathrm{N}\right)$, and Bombay, India (18 $58^{\prime} 45^{\prime \prime} \mathrm{N}$ ), and two dates of analysis (15 February and 15 August) using the methodology recommended by Allen et al. (1998).

If $32.59 \mathrm{MJ} \mathrm{m}^{-2}$ of solar radiation is required to disinfect a $0.20 \mathrm{~m}$ depth of TDWW, then two days of exposure will be required in Antofagasta and Mogadishu, in February, to obtain a reduction from an initial E. coli population of $3.5 \times$ $10^{6} \mathrm{MPN} / 100 \mathrm{~mL}$ to a desired final population of 1,000 MPN/100 mL. However, in Bombay, that reduction may not occur within two days. In Antofagasta, in August, disinfection under the circumstances mentioned above may not occur in two days, but in Mogadishu and Bombay, two days of exposure would be sufficient.

\section{Conclusions}

The present study demonstrated that solar radiation can be used to disinfect TDWW to an adequate level for use in fertigation. Disinfection to levels lower than 1,000 MPN/ $100 \mathrm{~mL}$ was obtained during the trials, which meets the WHO recommendations for unrestricted irrigation (category A water: $<1,000 \mathrm{MPN} / 100 \mathrm{~mL}$ ). Disinfection of TDWW using solar radiation in a concrete reactor was shown to be effective when the depth of the wastewater was less than $0.20 \mathrm{~m}$, which was the maximum depth tested in this research, and the exposure time was sufficient. A model developed to simulate and design TDWW solar disinfection units using depth of wastewater and UV dose accumulated as independent variables and the initial $E$. coli population as dependent variable proved to adequately describe experimental data.

\section{ACKNOWLEDGEMENTS}

The authors thank the Brazilian Scientific and Technological Development Council (CAPES/PEC-PG), Fundo de Apoio à Pesquisa de Minas Gerais (FAPEMIG), and the Agricultural Engineering Department of the Universidade Federal de Viçosa for financial support of this work.

\section{REFERENCES}

ABNT. 1993. Projeto, construção, e operação de tanques sépticos. NBR:7229. Rio de Janeiro, Brazil: Associação Brasileira de Normas Técnicas.

Acra, A., Z. Raffoul, and Y. Karahagopian. 1984. Solar disinfection of drinking water and oral rehydratation solutions: Guidelines for household application in developing countries. New York, N.Y.: UNICEF Publications.

Acra, A., M. Jurdi, H. Mu'allem, Y. Karahagopian, and Z. Raffoni. 1997. Water disinfection by solar radiation: Assessment and application. Ottawa, Ontario, Canada: IDRC.

Allen, R. G., L. S. Pereira, D. Raes, and M. Smith. 1998. Crop evapotranspiration: Guidelines for computing crop water requirements. FAO Irrigation and Drainage Paper 56. Rome, Italy: United Nations FAO.

APHA. 1995. Standard Methods for the Examination of Water and Wastewater. 19th ed. Washington, D.C.: American Public Health Association.

Burgess, S., and C. Onyonge. 2002. Solar disinfection of water (A case study from Kenya). In Proc. 2 8th WEDC Conference: Sustainable Environmental Sanitation and Water Services, 51-54. Leicestershire, U.K.: Loughborough University, Water, Engineering, and Development Centre.

Caslake, L. F., D. J. Connolly, V. Menon, C. M. Duncanson, R. Rojas, and J. Tavakoli. 2004. Disinfection of contaminated water by using solar irradiation. Applied and Environ. Microbiol. 70(2): 1145-1150.

Crawley, M. J. 2002. Statistical Computing: An Introduction to Data Analysis using S-Plus. Chichester, U.K.: John Wiley and Sons.

Cooper, R. C. 1991. Public health concerns in wastewater use. Water Science and Tech. 24(9): 55-65.

Drangert, J. O. 1998. Fighting the urine blindness to provide more sanitation options. Water South Africa 24(2): 157-164.

Drechsel, P., U. J. Blumenthal, and B. Keraita. 2002. Balancing health and livelihoods: Adjusting wastewater irrigation guidelines for resource-poor countries. Urban Agric. Magazine (Dec.): 7-9.

Iqbal, M. 1983. An Introduction to Solar Radiation. Toronto, Canada: Academic Press.

Joyce, T. M., K. G. McGuigan, M. Elmore-Meegan, and R. M. Conroy. 1996. Inactivation of fecal bacteria in drinking water by solar heating. Applied and Environ. Microbiol. 62(2): 399-402.

Kehoe, S. C., T. M. Joyce, P. Ibrahim, J. B. Gillespie, R. A. Shahar, and K. G. McGuigan. 2001. Effect of agitation, turbidity, aluminum foil reflectors, and container volume on the inactivation efficiency of batch-process solar disinfectors. Water Research 35(4): 1061-1065.

Kirk, J. T. O. 1994. Light and Photosynthesis in Aquatic Ecosystems. 2nd ed. Cambridge, U.K.: Cambridge University Press.

Koller, L. R. 1952. Ultraviolet Radiation. New York, N.Y.: John Wiley and Sons.

Kowalski, W. J. 2001. Design and optimization of UVGI air disinfection systems. PhD diss. University Park, Pa.: Pennsylvania State University, Department of Architectural Engineering.

Kowalski, W. J., W. P. Bahnfleth, D. L. Witham, B. F. Severin, and T. S. Whittam. 2000. Mathematical modeling of ultraviolet germicidal irradiation for air disinfection. Quantitative Microbiol. 2(3): 249-270.

Liou, K. 1980. An Introduction to Atmospheric Radiation. San Diego, Cal.: Academic Press.

Metcalf and Eddy. 1979. Wastewater Engineering: Treatment, Disposal, and Reuse. 3rd ed. New York, N.Y.: McGraw-Hill.

McGuigan, K. G., T. M. Joyce, R. M. Conroy, J. B. Gillespie, and M. Elmore-Meegan. 1998. Solar disinfection of drinking water 
contained in transparent plastic bottles: Characterizing the bacterial inactivation process. J. Applied Microbiol. 84(6): 1138-1148.

Oates, P. M., P. Sanan, and M. F. Polz. 2003. Solar disinfection (SODIS): Simulation of solar radiation for global assessment and application for point-of-use water treatment in Haiti. Water Research 37(1): 47-57.

Postel, S. 2000. Redesigning irrigated agriculture. In Proc. 4th Decennial National Irrigation Symposium, 1-12. St. Joseph, Mich.: ASAE.

Ratkowsky, D. A. 1989. Handbook of Nonlinear Regression Models. New York, N.Y.: Marcel Dekker.

Rosegrant, M. W., X. Cai, and S. A. Cline. 2002. World Water and Food to 2025: Dealing with Scarcity. Washington, D.C.: International Food Policy Research Institute.

Saitoh, T. S., and H. El-Ghetany. 2002. A pilot solar water disinfection system: Performance analysis and testing. Solar Energy 72(3): 261-269.

Salih, F. M. 2003. Formulation of a mathematical model to predict solar water disinfection. Water Research 37(16): 3921-3927.

Severin, B. F., M. T. Suidan, and R. S. Engelbrecht. 1983. Kinetic modeling of UV disinfection of water. Water Research 17(11): 1669-1678.

Solarte, Y., M. L. Salas, B. Sommer, C. Dierolf, and M. Wegelin. 1997. Uso de la radiación solar (UV-A y temperatura) en la inactivación del Vibrio cholerae en agua para consumo humano: Factores que condicionan la eficiencia del proceso. Colombia Médica 28(3): 123-129.
Strauss, M. 2000. Human waste (excreta and wastewater) reuse. Duebendorf, Switzerland: Swiss Federal Institute for Aquatic Science and Technology, Department of Water and Sanitation in Developing Countries. Available at: www.sandec.ch. Accessed 30 July 2003.

Wegelin, M. S. Canonica, K. Mechsner, T. Fleischmann, F. Pesaro, and A. Metzler. 1994. Solar water disinfection: Scope of the process and analysis of radiation experiments. J. Water SRT Aqua 43(3): 154-169.

WHO. 1989. Health guidelines for the use of wastewater in agriculture and aquaculture. Report of a WHO Scientific Group. WHO Technical Report Series, No. 778. Geneva, Switzerland: World Health Organization.

Windland, U., S. Esrey, J. Gough, D. Rapaport, R. Sawyer, M. Simpson-Hébert, and J. Vargas. 1999. Saneamiento Ecológico. U. Windland, ed. Distrito Federal (D.F.), Mexico: Fundación Friedrich Ebert, Agencia de Cooperación Internacional para el Desarrollo.

Yoon, C. G., K. W. Chung, J. I. Ham, and J. H. Jeon. 2004. Feasibility study of UV disinfection for agricultural reuse of secondary-level effluent in Korea. J. Environ. Sci. and Health A39(3): 835-846. 
